\title{
CORRELATION COMMUNICATION COMMUNICATION PERFORMANCE OF GENERAL \\ BETWEEN \\ AND \\ WITH \\ THE DPD \\ INTERPERSONAL LEADERSHIP THE EMPLOYEE RI SECRETARIAT-
}

\section{Sila Nirmala*}

The Secretariat General of the Regional Representative Council of the Republic of Indonesia

*Correspondence: silanirmala98@gmail.com

\author{
ARTICLE INFO \\ Article History: \\ received: 03/09/2020 \\ revised: $05 / 11 / 2020$ \\ accepted: 29/12/2020

\section{Keywords:} \\ Leadership Communication; \\ Interpersonal \\ Communication; Employee \\ Performance
}

DOI:

\section{INTRODUCTION}

Organizations develop along with the development of science, technological knowledge, besides that the development of the organization cannot be separated from the role of human resources. Human

\begin{abstract}
This research was carried out by formulating the following problems: (1) Is there a relationship of leadership communication with the performance of the DPD Secretariat General's staff? (2) Is there a relationship between interpersonal communication and the performance of the DPD Secretariat General's staff? (3) Is there a relationship between leadership communication and interpersonal communication with the performance of employees of the DPD Secretariat General? To answer the formulation of the problem above, this research was conducted with a survey method with a quantitative approach, namely associative descriptive. The population in this study were employees of the DPD Secretariat General, with a sample of 90 people. Sampling method using a purposive sampling method. The data collection method used is the questionnaire method. The data analysis method used is the analysis of partial correlation and multiple correlation analysis. The results showed that: (1) The relationship between leadership communication and employee performance obtained the number $\mathrm{t}$ count $(3.091)>t$ table $(2,675)$, a significant number of $0,000<0,05$ and, a correlation number of $0,500(25 \%)$ means that there is a significant relationship. (2) The relationship between interpersonal communication and employee performance is obtained by the number $t$-count (7.105)> t-table (2.675), a significant number of $0.000<0.05$ and, a correlation number of $0.711(50.5 \%)$ means that there is a significant relationship. (3) The relationship between leadership communication and interpersonal communication with employee performance obtained Fcount number $(11,626)>$ F-table $(1,605)$ significant number $0,000<0,05$ and correlation number $0,795(63,2 \%)$ means that there is a significant relationship.
\end{abstract}

resources are individuals who have the ability and are part of the organization. Human resources in the organization consist of leaders as well as subordinates. Leaders and subordinates are interrelated, if the leader does not understand the work needs 
and welfare needs of subordinates, job dissatisfaction will arise because subordinates are not well-motivated, while motivation refers to needs.

In terms of human resource management, satisfaction problems often arise, which are caused by communication of leadership, competence, compensation, facilities and, infrastructure. However, from the communication factor, it is rarely mentioned that communication can improve employee performance.

The employee and organization are inseparable things. Employees play an important role to smooth out running of organization of the organization's wheels, if the employee's work productivity is high, the wheels of the organization will also run smoothly, on the other hand, if employees are not productive, the wheels of the organization will be disrupted. Productive or not employee performance depends on several things including leadership communication, communication between employees (interpersonal communication), and so on. Travel administrative activities are not only carried out individually, but work activities must be carried out together, meaning that there must be verbal communication through effective communication. Every day employees must communicate with their leaders or fellow subordinates, and vice versa. Work can run well if supported by effective communication. Everett $M$. Rogers expressed his opinion that "Communication is a process where an idea is transferred from the source to an acceptance or more with the intention of changing their behavior". Another opinion from Rogers and O. Lawrence Kincaid "Communication is an interaction where there are two or more people who are building or exchanging information with each other which will eventually arrive where they understand and understand each other". From this understanding of communication, within the organization directly or indirectly, whether we realize it or not, there has been communication.
Organizations are inseparable from communication so that if communication within the organization runs with overlap, in theory, effective communication is obtained. Devito (1997: 337) explains organization as a group of individuals organized to achieve certain goals, while organizational communication according to Deddy Mulyana, (2007: 83) Communication occurs within an organization, is formal and also informal, and take place in a larger network than group communication. Therefore, the organization can be defined as a group of groups. Organizational communication often involves sister communication, interpersonal communication. Formal communication is communication according to the organizational structure, namely downward communication, upward communication, and horizontal communication, while informal communication does not depend on organizational structure, such as communication between peers, also includes gossip and gossip.

The Secretariat General of the Regional Representative Council of the Republic of Indonesia (Setjen DPD RI) is an organization engaged in politics, where the General Secretariat of the DPD RI is one of the legislative institutions in Indonesia besides the MPR and DPR. The DPD RI General Secretariat is inseparable from human resources who understand the performance of employees, so that in addition to the determinants of employee performance, in the DPD RI Secretariat General organization there are also some leaders and employees who work supported by communication.

The main problem is employee performance. In general, not all employees have high-performance, there are still highperformance appraisals in terms of management factors, namely competence, compensation, work environment, and others. At the DPD RI General Secretariat, employees are also not yet fully performing, this is due to one of the factors of communication, namely leadership 
communication carried out by the leadership, because according to employees that the leadership often provides limited communication, or even communicates only nonverbally. With ineffective leadership communication, miss communication often occurs, resulting in the work being not maximum.

Furthermore, complaints arise from interpersonal communication factors, namely the occurrence of work that is stopped or disruption of work results due to a lack of good communication between leaders and subordinates as well as between fellow staff and also the relationship between them, because there is no immediate response or feedback from the communicator or the person providing messages, while interpersonal communication is the process of exchanging information between someone else or usually between two people which can be immediately known to reverse it (Muhammad,2005:158-159).

The organization must be able to recognize what factors make employees have high performance in working in the organization. With good performance, productivity also increases, thus the wheels of the organization can run smoothly.

The development of research is quite rapid, especially research on communication, namely interpersonal communication conducted in an organization or other institution. Various themes and topics about survey research are no exception case studies on performance related to leadership communication and interpersonal communication.

Isaac Idowu Abe and Roger B. Mason in Journal Problems and Perspective in Management (2016) entitled "The Role of Individual Interpersonal Relationship on work Performance in The South African Retail Sector" says that statistically, this study identified that interpersonal relationship is negatively associated with employee performance for subordinate employees, and weakly associated for supervisors in the South African retail sector. Explanations of the implications of the negative associations as obtained in this study have been offered to management. However, both the supervisors and the subordinate employees are of the view that if communication (listening), training, teamwork, respect, trust, information sharing, fair treatment of employees, and adequate understanding of tasks are enhanced by the management of the retail organizations, then the quality of a relationship will be high, such that it will positively influence employee performance.

Conclusion of research results from Idah Naile and Jacob M. Selesho (2014) in his research entitled "The Role of Leadership in Employee Motivation" that is the abovementioned results suggest that there is a positive relationship between the teaching staff and principal; that positive relationship between transformational leadership behaviors and commitment (affective commitment and continuance commitment). This suggests that leadership behaviors that involve building trust, inspiring a shared vision, encouraging creativity, and emphasizing development are positively related to employee commitment. While the study interrogates these two phenomena: that style can assist in the motivation of the teaching staff, it can be concluded that transformational leadership can be used to raise organizational commitment and employee performance.

Transformational leadership cannot raise job satisfaction. Rather, the commitment of teachers to their job can raise job satisfaction and ultimately improve the school's academic performance. On the other hand, job satisfaction can raise the employees' performance. To raise school academic performance, consideration should be given to the intellectual stimulation of individual teachers.

The leadership style that is accepted by the teaching staff will motivate, inspire and influence them when decisions and some problems arise. Furthermore, these styles can create positive, organizational commitment and promote job performance. 
The school principal, through his leadership style, can always increase organizational commitment by providing rewards to induce employees to work harder.

Based on the explanation above, this study aims to determine the relationship between leadership communication and interpersonal communication with the performance of the secretariat general employees of the regional representative council of the Republic of Indonesia. The benefit of this research is to add to the treasures of research on leadership communication and interpersonal communication carried out, as well as material for evaluation and input related to leadership communication and interpersonal communication at the General Secretariat of the Regional Representative Council of the Republic of Indonesia.

\section{Leadership Communication}

Leadership communication is a process of communication that a leader (as a communicator) does to subordinates of his organization (as a communion). In its application, leaders can use various types of leadership communication according to their respective styles that are influenced by many factors. This type of leadership communication or leadership communication style must be owned by a leader. This leadership communication style should be used by leaders to influence their subordinates to achieve organizational targets.

One of the popular and widely applied leadership communication theories is the Likert 4 System theory or 4 Leadership communication style. This theory is a managerial system theory based on several important managerial-related variables such as leadership, motivation, communication, interaction, decision making, goal setting, control, and performance. (Also read: Health Communication)

This theory of leadership communication is widely used to analyze the influence of leadership communication styles on changes in the performance of employees or subordinates. In Likert theory, leadership communication is distinguished by the following 4: Absolute $\mathrm{Or}$ Authoritarian Ruling Style, Semi Absolute Or Benevolent Authoritative Ruling Style, Advisory Or Consultative Leadership Style, Participatory Leadership Style.

Peter Sheal (2003:22) states that leadership is an improvement on our kinerja working with subordinates. A leader is categorized as follows: (a) can develop himself as a leader, (b) encourage a conducive work atmosphere, (c) can organize and train, (d) provide a brief job description and training, (e) can delegate work and responsibilities, (f) can observe and assess performance and work, (g) prepare and conduct work discussions.

According to Kotler (1996:23), there are 8 stages of leadership namely: (a) establishing the meaning of urgency, (b) forming a coalition of influences, (c) developing visions and strategies, (d) displaying visions of change, (e) empowering many people, (f) generating short-term gains, (g) consolidating achievements and generating more change, (h) establishing new approaches into a culture.

Leadership: 1. Must dare to make your own decisions firmly and appropriately (decision making). 2. Must be brave to accept your self risks. 3. Must dare to accept responsibility alone (The Principle of Absoluteness of Responsibility), responsibility should not be delegated down (Isaac Arep and Hendri Tanjung, 2002:235)

Thus it can be concluded that in this study for measurement of leadership communication variables using indicators: (a) Developing yourself as a leader, (b). Encouraging and motivating the work of employees, (c). Providing a brief description of employee work, (d). Providing responsibility and delegating work, (e). Observing and assessing work, (f) Conducting direction and discussion in the work. 


\section{Communication Interpersonal}

Interpersonal communication is communication that occurs between two or more people that is usually not formally regulated. In interpersonal communication, each participant used all elements of the communication process. For example, each party will discuss their respective backgrounds and experiences in the conversation (Communicating Effectively, 6 Edition, New York: McGraw-Hill,2001).

Devito provides a more specific definition of interpersonal communication as the communication that takes place between two people who have an established relationship. There are five general goals for humans to communicate interpersonally, namely: (1) To influence, (2) For a relationship, (3) To learn to know yourself, other people, the world, and to master skills, (4) To help others and (5) To play. Of these 5 goals, humans have the motivation and the results they want to expect.

Interpersonal communication is not much different from the form of behavior of people, there are times when effective there are times when it is ineffective. According to Miftah Thoha (2005:191), interpersonal communication can be effective with the following five things, namely:

a) Openness

To show the quality of openness of this interpersonal communication there are at least two aspects namely the aspect of wanting to be open to everyone who interacts with others and the other aspect is the desire to respond honestly to all the information that comes to it.

b) Empathy

It is intended to feel as felt by others that are trying to feel in the same way as the feelings of others.

c) Support

By this support will be achieved effective interpersonal communication. Support is sometimes unspoken and sometimes unspoken. Unspoken support such as head nods, winks, smiles, or applause is unspoken positive endorsements.

d) Positivity

Interpersonal communication will work if there is positive attention to one's self. Interpersonal communication will be well maintained if a positive feeling towards another person is communicated. A positive feeling in a general communication situation is very beneficial to effective cooperation.

e) Similarities

Interpersonal communication will be more effective if the people who communicate it are in an atmosphere of similarity. This is not to say that people who have nothing in common cannot communicate. They obviously can communicate, but if their communication wants to be effective, there should be personality similarities between them. So that the communication carried out will be more about the target because it will create mutual understanding.

\section{Performance}

According to Mangkunegara (2001), performance is the result of work in quality and quantity that can be achieved by an employee in carrying out duties in accord with the responsibilities given to him.

According to Amstrong and Baron quoted by Wibowo (2007:2), performance is doing work and the results achieved from the work include what is done and how to do it. Performance is the work of personnel both quantity and quality in an organization. Performance can be an individual appearance as well as a working performance of a group of personnel. The appearance of the work is not limited to personnel who hold functional and structural positions, but also to the entire ranks of personnel within the organization (Ilyas,2001).

Performance is the result or output of prose (Nurlaila, 2010:71). According to the behavioral approach in management, performance is the quantity or quality of something produced or services provided by 
someone doing the work (Luthans, 2005:165).

Performance or performance contains the meaning of work that can be achieved by a person known by a group of people in an organization in accord with their respective authority and responsibilities so that to achieve the objectives of the organization concerned legally, not breaking the law, and in accord with morals or ethics.

Irawan (2004:1) defines that performance as the work of a worker, a management process, or an organization as a whole where the results of work must be presented concretely and can be measured by predetermined benchmarks.

Some important keywords, namely the results of work, workers, certain processes, or organizations can be concretely measured, compared to predetermined standards. However, it should be understood that not all performance is easy to measure, easy to compare with standards, or concretely proven, for example, worker creativity is increasing and office management is getting neater.

The elements that are assessed or employee performance indicators based on law number 43 of 2004 concerning the main points of employment: Loyalty, work achievement, honesty, discipline, creativity, cooperation, leadership, personality, initiative, skills, and responsibility.

\section{METHOD}

This research is quantitative research, which emphasizes objective phenomena and is studied quantitatively. The maximization of the objectivity of quantitative research designs according to Sukmadinata (2009: 530 ) is carried out by using numbers, statistical processing, structure, and controlled experiments.

Data mining in this study was carried out by distributing questionnaires. The advantage of this survey is that it can obtain various information and the results can be used for other purposes.

The research method used in this writing is the Survey method, with the quantitative approach that is descriptively associative.

This can be explained as follows: First, it is seen from a large number of units of analysis (population), that data collection from the population will be less efficient. So, the authors took a more efficient way of capturing data sampling techniques. Second, by taking data through samples, and so that the data from the sample truly represent the characteristics of the population, the determinants of the sample as the unit of analysis in this study demand appropriate and accountable sampling techniques. For this reason, the authors took a purposive sampling technique.

Furthermore, seen from the type of data to be analyzed and tested in this study, is ordinal data (non-numeric ranked data) which is then scaled using a Likert-scale, so that the data becomes a cardinal scale. Thus, this research is quantitative and hypothetical.

This study used data collection techniques through questionnaires. A questionnaire is a data collection technique that is done by giving a set of questions or written statements to respondents to answer. And it is an efficient data collection technique when researchers know exactly what variables to measure and know what to expect from respondents.

Data analysis techniques in the research are processed and gradually discussed for each variable, in the following order: Raw data processing that is processing raw data from the research using descriptive statistics include parameters: 1 ). Central tendency such as mean, median, and mode; 2) Skewness; 3) Tapering (Kurtosis); Frequency Distribution; and graphs in the form of histograms and normal curves. Analysis requirements testing using the One-Sample Kolmogorov-Smirnov Test parameter.

Hypothesis testing using inferential statistics. This analysis is intended to test whether there is a relationship between the independent variables and the related variables. The steps for testing this 
hypothesis begin by looking for a simple regression equation, then multiple regression, resulting in an estimated measure in the form of a regression equation both simple and multiple linear regression. The regression equation is then tested, both the level of significance and the level of linearity, using the F-test based on the ANOVA table.

\section{RESULT AND DISCUSSION}

The results of this study discuss the results of research which is the final stage of the entire series of activities carried out in research starting from observing problems, compiling proposals, compiling instruments, distributing questionnaires, collecting and processing data using SPSS (Statistical Product and Service Solutions) software.

\section{Correlation between Leadership Communication with the Performance of Employees of the Secretariat General of DPD RI.}

Correlation calculation with SPSS program produces such description in the table below:

Table 1. Correlation of Leadership Communication (X1) with Employee Performance (Y)

\begin{tabular}{|c|c|c|c|}
\hline & & $\begin{array}{c}\text { Emploxee } \\
\text { Performance }(\mathrm{Y})\end{array}$ & $\begin{array}{l}\text { Leadership communication } \\
\text { (X1) }\end{array}$ \\
\hline \multirow{2}{*}{ Pearson Correlation, } & Emploxee Performance (Y) & 1,000 &, 500 \\
\hline & Leadership Communication (X1) &, 500 & 1,000 \\
\hline \multirow{2}{*}{ Sig (1-tailed) } & Emploxee Performance (Y) & . &, 000 \\
\hline & Leadership Communication (X1) & .000 & . \\
\hline \multirow[b]{2}{*}{$\mathrm{N}$} & Emploxee Performance $(\mathrm{Y})$ & 90 & 90 \\
\hline & Leadership Communication (X1) & 90 & 90 \\
\hline
\end{tabular}

Source: generated by SPSS, 2021

The table above shows that the correlation number (ry1) between Leadership Communication (X1) and Employee Performance (Y) is 0.500 . Furthermore, correlation significance testing is carried out to determine the nature of the relationship, namely as follows: Correlation coefficient testing is done through correlation coefficient test using t- test. This t-test is used to test the significance of the influence of each free variable on nonfree variables. Correlation calculation results $\mathrm{T}$ significance test is done by processing data using SPSS to produce data, where obtained t-count number $(3,091)>t$ table $(2,675)$ and a significant number $(0.000)<(0.05)$. 
Table 2. Correlation Significance Leadership Communication (X1)

\begin{tabular}{|c|c|c|c|c|c|c|}
\hline \multicolumn{7}{|c|}{ Coefficientsa } \\
\hline \multirow{2}{*}{\multicolumn{2}{|c|}{ Model }} & \multicolumn{2}{|c|}{$\begin{array}{c}\text { Unstandardized } \\
\text { Coefficients }\end{array}$} & \multirow{2}{*}{$\begin{array}{c}\text { Standardized } \\
\text { Coefficients } \\
\\
\text { Beta }\end{array}$} & \multirow{3}{*}{$\frac{\mathrm{t}}{3,091}$} & \multirow{3}{*}{$\frac{\text { Sig. }}{, 003}$} \\
\hline & & B & Std. Error & & & \\
\hline \multirow{2}{*}{\multicolumn{2}{|c|}{ 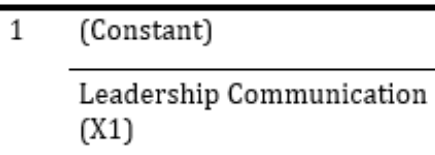 }} & 24,308 & 7,864 & & & \\
\hline & & ,638 & 158 &, 500 & 4,039 &, 000 \\
\hline
\end{tabular}

Source: generated by SPSS, 2021

Thus it can be concluded that the correlation number of 0.500 is a positive relationship between Leadership Communication $\left(\mathrm{X}_{1}\right)$ and Employee Performance $(\mathrm{Y})$ with a moderate level. The results of the t-test above shows that the correlation between Leadership Communication and Employee Performance $(\mathrm{Y})$ is very meaningful (significant). The relationship indicates that even at a moderate response rate, but if the
Leadership Communication variable $\left(\mathrm{X}_{1}\right)$ rises, then the Employee Performance variable (Y) also rises. Conversely, if the Leadership Communication variable $\left(\mathrm{X}_{1}\right)$ decreases, then the Employee Performance variable $(\mathrm{Y})$ also decreases. The correlation between the Leadership Communication variable $\left(\mathrm{X}_{1}\right)$ and the Employee Performance variable $(\mathrm{Y})$ is 0.500 . Thus the coefficient of determination is ry22 $=0.5002=0.25 \times 100$ $=25 \%$.

Table 3. Coefficient of Determination of Leadership Communication (X1) on Employee Performance (Y)

\begin{tabular}{|c|c|c|c|c|}
\hline & & & & \\
Model & $\mathrm{R}$ & R Square & Adjusted R Square & $\begin{array}{c}\text { Std. Error of the } \\
\text { Estimate }\end{array}$ \\
\hline 1 &, $500^{\mathrm{a}}$ &, 250 &, 235 & 5,587 \\
\hline
\end{tabular}

Source: generated by SPSS, 2021

The coefficient of determination means that $25 \%$ of Employee Performance is determined by leadership communication variables, while the other $75 \%$ is determined by other factors. The correlation between the Leadership Communication variable $\left(\mathrm{X}_{1}\right)$ and the Employee Performance variable (Y) is 0.500 , resulting in a partial correlation of 0.300. The figure indicates that the relationship between the Leadership Communication variable $\left(\mathrm{X}_{1}\right)$ and the Employee Performance variable (Y) increased by 0.200 when controlled by Interpersonal Communication $\left(\mathrm{X}_{2}\right)$ level.
Interpersonal

Communication

Relationship With the Performance of Employees of the Secretariat General of DPD RI.

This can be seen from the results of the correlation significance test using SPSS obtained $t$ count number $(7,105)>t$ table $(2,675)$ and significance number $(0.000)<$ 0.05 . thus it can be concluded that the correlation number of 0.711 is a positive relationship between Interpersonal Communication $\left(\mathrm{X}_{2}\right)$ and Employee Performance $(\mathrm{Y})$ with a moderate from the 
results of the t-test above shows that the correlation between Interpersonal Communication $\left(\mathrm{X}_{2}\right)$ and Employee Performance $(\mathrm{Y})$ is very meaningful (significant). The relationship indicates that at a moderate response rate, if the
Interpersonal Communication $\left(\mathrm{X}_{2}\right)$ variable rises, then the Employee Performance variable (Y) also rises. Conversely, if the Interpersonal Communication $\left(\mathrm{X}_{2}\right)$ variable falls, then the Employee Performance variable (Y) also decreases.

Table 4. Correlation Significance Test Between Interpersonal Communication (X2) And Employee Performance (Y)

Model Summary

\begin{tabular}{|l|r|r|r|r|}
\hline Model & \multicolumn{1}{|c|}{ R } & R Square & \multicolumn{1}{c|}{$\begin{array}{c}\text { Adjusted R } \\
\text { Square }\end{array}$} & Std. Error of the Estimate \\
\hline 1 &, 711 &, 560 &, 549 & 5,690 \\
\hline
\end{tabular}

Source: generated by SPSS, 2021

From the table below, the correlation between the interpersonal communication variable and the Employee Performance variable $(\mathrm{Y})$ is 0.711 . Thus the coefficient of determination is ry $_{12}=0.7112=0.505 \times 100$
$=50.5 \%$. The coefficient of determination means that $50.5 \%$ of Employee Performance is determined by the Interpersonal Communication variable, while the other $49.5 \%$ is determined by other factors.

Table 5. Coefficient of Determination Between Interpersonal Communication Variables (X2) And Employee Performance (Y)

\begin{tabular}{|c|c|c|c|c|c|c|}
\hline \multicolumn{7}{|c|}{ Coefficientsa } \\
\hline \multirow{4}{*}{$\begin{array}{l}\text { Model } \\
1\end{array}$} & & Unstandardize & Coefficients & $\begin{array}{l}\text { Standardized } \\
\text { Coefficients }\end{array}$ & & \\
\hline & & B & Std. Error & Beta & $\mathrm{t}$ & \\
\hline & (Constant) & 56,986 & 10,214 & & 5,579 & ,216 \\
\hline & $\begin{array}{l}\text { Interpersonal } \\
\text { Communication }\left(\mathrm{X}_{2}\right)\end{array}$ & 711 & 097 & ,711 & 7,105 &, 000 \\
\hline
\end{tabular}

Source: generated by SPSS, 2021

The correlation between the Interpersonal Communication variable $\left(\mathrm{X}_{2}\right)$ and the Employee Performance variable $(\mathrm{Y})$ is 0.711 . The figure indicates that the relationship between the Interpersonal Communication $\left(\mathrm{X}_{2}\right)$ variable and the Employee Performance variable (Y) decreased by 0.183 when controlled by Leadership Communications $\left(\mathrm{X}_{1}\right)$.

\section{Relationship of Leadership Communication And Interpersonal Communication With The Performance of Employees of the Secretariat General of DPD RI}

Correlation Significance Test Results using SPSS produce data as contained in the table obtained calculated F number (11.626) $>$ F table $(1,605)$ with a significance level of $0.000<0.05$. thus it can be concluded that correlation number 0.795 is a positive relationship between Leadership Communication $\left(\mathrm{X}_{1}\right)$ and Interpersonal Communication $\left(\mathrm{X}_{2}\right)$ with strong Employee Performance (Y). The results of the t-test above show that the correlation between Leadership Communication $\left(\mathrm{X}_{1}\right)$ and Interpersonal Communication $\left(\mathrm{X}_{2}\right)$ with Employee Performance (Y) is very meaningful (significant). With a strong level, the relationship shows that at a strong 
response level, that is, together if the variables of Leadership Communication $\left(\mathrm{X}_{1}\right)$ and Interpersonal Communication $\left(\mathrm{X}_{2}\right)$ rise, then the employee performance variable $(\mathrm{Y})$ also rises. Conversely, if the variables of
Leadership Communication $\left(\mathrm{X}_{1}\right)$ and Interpersonal Communication $\left(\mathrm{X}_{2}\right)$ decrease, then the Employee Performance variable $(\mathrm{Y})$ also decreases.

Table 6. Correlation of Leadership Communication $\left(\mathrm{X}_{1}\right)$ and Interpersonal Communication ( $\left.\mathrm{X}_{2}\right)$ to Employee Performance (Y)

\begin{tabular}{rrrr}
\multicolumn{1}{c}{ Ranking } & \multicolumn{2}{c}{ Koefisien } & \multirow{2}{*}{ Percent } \\
\cline { 1 - 2 } Free Variables & R (r) & $\mathbf{R}^{2}\left(\mathbf{r}^{2}\right)$ & \\
\hline X1 and X2 with Y & 0,795 & 0,632 & 63,2 \\
X2 and Y & 0,711 & 0,560 & 56,0 \\
X1 and Y & 0,500 & 0,250 & 25,0 \\
\hline
\end{tabular}

Source: generated by SPSS, 2021

The correlation between the Interpersonal Communication Leadership Communication (X2) variable together with the Employee Performance variable (Y) is 0.795. Thus the coefficient of determination is ry $12=0.7952=0.632 \times 100=63.2 \%$. The coefficient of determination means that $63.2 \%$ of Employee Performance is determined by leadership communication variables, while the other $36.8 \%$ is determined by other factors.

Table 7. Correlation Coefficient Ranking and Coefficient of Determination of each Free Variable against Bound Variables

\begin{tabular}{|c|c|c|c|c|c|c|}
\hline \multicolumn{7}{|c|}{ ANQYAa } \\
\hline & Model & Sum of Squares & df & Mean Square & $\mathrm{F}$ & Sig. \\
\hline \multirow[t]{3}{*}{1} & Regression & 102,651 & 2 & 51,325 & 11,626 &, $000^{\mathrm{a}}$ \\
\hline & Residual & 2746,638 & 87 & 31,571 & & \\
\hline & Total & 2849,289 & 89 & & & \\
\hline
\end{tabular}

Source: generated by SPSS, 2021

The table shows that: First, the relationship together between the Leadership Communication variable (X1) and the Interpersonal Communication variable (X2) with the Employee Performance variable $(\mathrm{Y})$, is the first rank with a correlation coefficient (Ry12) $=0.795$ and a determinant coefficient (Ry122) = $0.632=63.2 \%$. Second, the relationship between the Interpersonal Communication variable (X2) and the Employee Performance variable (Y) is the second rank, with the correlation coefficient (ry2) $=0.711$ and the determinant coefficient (ry12) = $0.560=56 \%$. Third, the relationship between the Leadership Communication variable (X1) and the Employee Performance variable (Y), is the second rank, with the correlation coefficient (ry1) $=0.500$ and the coefficient of determination (ry22) = $0.250=25 \%$.

\section{CONCLUSION}

Based on the results of hypothesis testing that has been done, it can be concluded the following: 
a. There is a significant relationship between Leadership Communication and Employee Performance that is positive and is at the level of a relationship while this is indicated by the correlation coefficient ry $1=0.500$ and the coefficient of determination of $25 \%$.

b. There is a significant relationship between Interpersonal Communication and Employee Performance that is positive and at the level of strong relationships. This is indicated by the correlation coefficient ry $2=0.711$.

c. There is a significant relationship between leadership communication and interpersonal communication with positive employee performance and is at a very strong level of relationship. This is indicated by the correlation coefficient ry $2=0.795$.

To the organization of work in the Secretariat General of DPD RI, can be given advice that may be useful in developing employee performance, as follows:

a. It is recommended that the leadership review its communication with subordinates, so that leadership communication becomes more effective, especially when it comes to providing cognizance and delegating work.

b. To strengthen interpersonal communication to support the performance of employees need to foster a sense of empathy that is by fostering a sense of desire to help colleagues who still do not understand or do not understand the work to be completed.

c. Employee performance improvement needs to be done, especially in terms of cooperation, namely by implementing an attitude of mutual assistance in completing work.

d. It is necessary to pay attention to other factors outside of leadership communication and interpersonal communication that are quite influential on employee performance, namely competence, compensation, culture, leadership, organizational climate, and so on.

\section{REFERENCE}

Anwar Prabu Mangkunegara, 2005, Human Resources of The Company, Bandung: PT. Remaja Rosdakarya.

Alo Liliweri, 1991, Understand The Role of Mass Communication in Society, Bandung: Citra Aditya Bakti

Arni Muhammad, 2005, Organizational Communication, Jakarta: Bumi Aksara

Besterfield, Dale H. et al, 2003, Total Quality Management, New Jersey: Pearson Education Inc

Bilson Simamora, 2002, Consumer Behavior Research Guidelines, Jakarta: Pustaka Utama

Deddy Mulyana, 2007, Communication Science: an Introduction, Bandung: PT. Remaja Rosdakarya

Devito Joseph, 1997, Communication Between Humans, Jakarta: Profesional Book

Ermaya Suradinata, 2005, Geopolitic dan Geostrategic, Jakarta: Suara Bebas

Henry Simamora, 2004, Human Resource Management, Yogyakarta: STIE YKPN

Irawan, 2004, Strategi Meningkatkan Kinerja Perusahaan, Bandung: PT. Remaja Rosdakarya

Jalaludin Rakhmat, 2005, Psikologi Komunikasi, Bandung: PT. Remaja Rosdakarya

Jonathan Sarwono, 2009, Statistik Itu Mudah: Panduan Lengkap Untuk Belajar Komputasi Statistik Menggunakan SPSS 16 (Yogyakarta: Universitas Atmajaya)

Kartini Kartono, 2009, Pemimpin dan Kepemimpinan, Jakarta: RajaGrafindo Persada

Malayu P. Hasibuan, 2006, Manajemen Sumber Daya Manusia, Edisi Revisi, Jakarta: PT. Bumi Aksara

Malayu P. Hasibuan, 2003, Manajemen Sumber Daya Manusia, Jakarta: PT. Bumi Aksara 
Manullang, 2005, Dasar-Dasar Manajemen, Bandung: Citra Pustaka

Morissan, 2013, Teori Komunikasi Individu Hingga Manusia, Jakarta: Kencana

Miftah Thoha, 2010, Perilaku Organisasi, Jakarta: RajaGrafindo Persada

Mulyana Deddy, 2007, IImu Komunikasi: Suatu Pengantar, Bandung: Remaja Rosdakarya

R.Wayne Pace \& Don F. Faules, 2006, Komunikasi Organisasi: Strategi Meningkatkan Kinerja Perusahaan, Bandung: PT. Remaja Rosdakarya

Robbins SP dan Judge, 2002, Perilaku Organisasi, Jakarta: Salemba

Sartono Kartodirdjo, 2004, Kepemimpinan Dalam Dimensi Sosial, Jakarta: Pustaka Jaya

Siagian P. Sondang, 2005, Manajemen Sumber Daya Manusia, Yogyakarta: Pustaka Pelajar

Sugiyono, 2011, Metode Penelitian Manajemen, Bandung: Alfabeta

Sugiyono, 2012, Metode Penelitian Pendidikan Pendekatan Kuantitatif Kualitatif dan $R \& D$, Bandung: Alfabeta

Wahjosumidjo, 2003, Kepemimpinan Kepala Sekolah, Jakarta: PT. RajaGrafindo Persada

Wibowo, 2007, Manajemen Kinerja, Jakarta: PT. RajaGrafindo Persada

Wiryanto, 2005, Pengantar Ilmu Komunikasi, Bandung: Gramedia Wiasarana Indonesia

Wursanto, 2005, Dasar-Dasar Ilmu Organisasi, Yogyakarta: Andi

Yuki Gary, 2010, Kepemimpinan Dalam Organisasi, Edisi Kelima, Jakarta: PT. Indeks

Undang-Undang Nomor 43 Tahun 2004 Tentang Pokok-Pokok Kepegawaian

Isaac Idowu Abe and Roger B. Mason (2016) "The Role of Individual Interpersonal Relationship on Work Performance in The South African Retail Sector" Journal Problems and Perspectives in Management $14 \quad(2-1)$. Doi: 10.21511/ppm.14 (2-1).2016.08

Idah Naile and Jacob M.Selesho (2014) "The Role of Leadership in Employee
Motivation" Mediterranean Journal of Social Sciences, MCSER Publishing, Rome-Italy, E-ISSN 2039-2117, ISSN 2039-9340, Doi: 